\section{Requirement of fibroblast growth factor 10 in development of white adipose tissue}

\author{
Hiroshi Sakaue, ${ }^{1,5}$ Morichika Konishi, ${ }^{2,5}$ \\ Wataru Ogawa, ${ }^{1}$ Toshiyuki Asaki, ${ }^{2}$ \\ Toshiyuki Mori, ${ }^{1}$ Masahiro Yamasaki, ${ }^{2}$ \\ Masafumi Takata, ${ }^{1}$ Hikaru Ueno, ${ }^{3}$ Shigeaki Kato, ${ }^{4}$ \\ Masato Kasuga, ${ }^{1,6}$ and Nobuyuki Itoh ${ }^{2,6}$
}

${ }^{1}$ Department of Clinical Molecular Medicine, Division of Diabetes, Digestive and Kidney Diseases, Kobe University Graduate School of Medicine, Chuo-ku, Kobe 650-0017, Japan; ${ }^{2}$ Department of Genetic Biochemistry, Kyoto University Graduate School of Pharmaceutical Sciences, Kyoto 606-8501, Japan; ${ }^{3}$ Department of Biochemistry and Molecular Physiology, University of Occupational and Environmental Health, School of Medicine, Kitakyushyu 807-8555, Japan; ${ }^{4}$ Institute of Molecular and Cellular Biosciences, University of Tokyo, Tokyo 113-0032, Japan

Fibroblast growth factors (FGFs) are important intercellular signaling molecules in developmental processes. Here, we show that FGF10 is secreted by cultured preadipocytes and that prevention of FGF10 signaling inhibits the expression of $C / E B P \beta$ and the subsequent differentiation of these cells. An active form of C/EBP rescued differentiation of the cells in which FGF10 signaling was blocked. Development of white adipose tissue and the expression of C/EBP $\beta$ in this tissue of FGF10 knockout mice were markedly reduced, and the ability of embryonic fibroblasts derived from FGF10 knockout mice to differentiate into adipocytes was impaired. Therefore, FGF10 plays an important role in adipogenesis, at least partly by contributing to the expression of C/EBP $\beta$ through an autocrine/paracrine mechanism.

Received February 8, 2002; revised version accepted March 1, 2002.

Adipose tissue contributes to regulation of energy balance, not only by serving as a reservoir of triglycerides but also by secreting circulating factors that affect food intake or metabolism (Hwang et al. 1997; Rosen and Spiegelman 2000; Fruebis et al. 2001; Steppan et al. 2001). Mature adipocytes do not undergo cell division; the number of these cells is therefore thought to increase as a result of the proliferation of preadipocytes and their subsequent differentiation into mature adipocytes. Various factors secreted by adipocytes or preadipocytes have been identified (Hwang et al. 1997; Rosen and Spiegelman 2000; MacDougald and Mandrup 2002), some of

\footnotetext{
[Key Words: FGF10; adipogenesis; differentiation; C/EBP 3 ] ${ }^{5}$ These authors contributed equally to this work. ${ }^{6}$ Corresponding authors.

E-MAIL kasuga@med.kobe-u.ac.jp; FAX 81-78-382-2080. E-MAIL itohnobu@pharm.kyoto-u.ac.jp; FAX 81-75-753-4600. Article and publication are at http://www.genesdev.org/cgi/doi/10.1101/ gad.983202.
}

which, such as tumor necrosis factor- $\alpha$ (Petrunschke and Hauner 1994), Pref-1 (Smas et al. 1997), and Wnt-10b (Ross et al. 2000), regulate adipogenesis by inhibiting the differentiation of these cells. Although factors that promote the proliferation or differentiation of preadipocytes have also been shown to be secreted by such cells isolated from obese humans (Lau et al. 1987) or by mature rat adipocytes (Schillabeer et al. 1989), the nature of these factors has remained unclear.

The fibroblast growth factor (FGF) family comprises at least 23 proteins (Yamashita et al. 2000; Ornitz and Itoh 2001) that function in an autocrine or paracrine manner and play important roles in the development, maintenance, and repair of tissues (Goldfarb 1996; Ornitz and Itoh 2001). FGF10 was initially identified in rat embryos by homology-based polymerase chain reaction (PCR; Yamasaki et al. 1996). Disruption of the FGF10 gene resulted in complete absence of limb bud formation and severe defects in the branching morphogenesis of the lung (Min et al. 1998; Sekine et al. 1999), indicating that FGF10 is important for development of these organs. On the other hand, we have previously shown that, among the major adult tissues, transcripts of the FGF10 gene are most abundant in adipose tissue (Yamasaki et al. 1999). Brown adipose tissue (BAT) and white adipose tissue (WAT) constitute the two principal types of adipose tissue and perform distinct functions (Hwang et al. 1997; Rosen and Spiegelman 2000). The expression of FGF10 is restricted to WAT. In particular, FGF10 mRNA is present in the vascular-stromal fraction of WAT (Yamasaki et al. 1999), a major component of which is adipocyte precursors. These observations prompted us to investigate the role of FGF10 in adipogenesis, and here we report that this signaling molecule plays a crucial role in the development of WAT via regulating differentiation of preadipocytes.

\section{Results and Discussion}

Exposure of 3T3-L1 preadipocytes, a well-characterized model for studying the differentiation of white adipocytes, to insulin, dexamethasone (DEX), and isobutylmethylxanthine (IBMX) resulted in the differentiation of most of the cells into mature adipocytes within $8 \mathrm{~d}$. The amount of FGF10 mRNA increased during such treatment, becoming maximal at $2 \mathrm{~d}$ and returning to basal values by $6 \mathrm{~d}$, whereas the mRNA for peroxisome proliferator-activated receptor $\gamma(\operatorname{PPAR} \gamma)$, a transcription factor essential for adipocyte differentiation, was apparent within $2 \mathrm{~d}$ and increased in abundance thereafter (Fig. 1A). The amount of FGF10 protein, both in cell lysates and in the culture medium, was also increased at $2 \mathrm{~d}$, and had returned to basal levels by $8 \mathrm{~d}$, after induction of differentiation of 3T3-L1 cells (Fig. 1B). A similar temporal profile of FGF10 mRNA abundance was observed when vascular-stromal cells derived from mouse epididymal adipose tissue were treated with insulin, dexamethasone, and IBMX (Fig. 1C). These results indicated that FGF10 is transiently expressed and secreted into the culture medium during differentiation of preadipocytes.

Antibodies specific to FGF10 (FGF10Ab), but not control immunoglobulin (IgG), inhibited activation of signaling molecules such as MAP kinase or p70S6 kinase in 
A

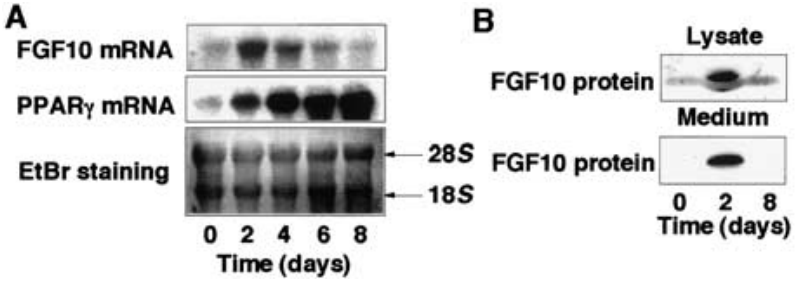

C

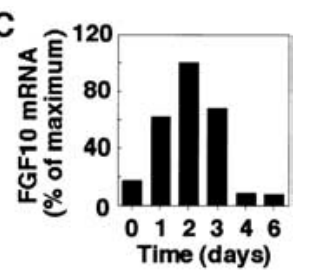

Figure 1. Time course of the expression of FGF10 during differentiation of preadipocytes. $(A, B)$ 3T3-L1 cells or $(C)$ stromal-vascular cells from mouse epididymal adipose tissue incubated for the indicated times after the onset of exposure to inducers of differentiation were subjected to Northern blot analysis for FGF10 or PPAR $\gamma(A)$, or to immunoblot analysis for FGF10 $(B)$, or to real-time RT-PCR analysis to determine FGF10 mRNA $(C)$. The data in $A$ and $B$ are representative of three experiments, those in $C$ of two experiments.

3T3-L1 preadipocytes induced by FGF10 (data not shown), indicating that the preadipocytes express an FGF receptor (FGFR) isoform that interacts with FGF10 and that these antibodies prevent the signal evoked by FGF10 by neutralizing the ligand. Addition of FGF10Ab, but not control IgG, to the induction medium inhibited the differentiation-associated lipid accumulation as well as expression of adipocyte-marker proteins such as $\mathrm{CCAAT} /$ enhancer-binding protein $\mathrm{C} / \mathrm{EBP} \alpha, \operatorname{PPAR} \gamma$, adipsin, and aP2, whereas expression of CREB, a transcription factor involved in differentiation of preadipocytes, was not affected by these antibodies at $8 \mathrm{~d}$ after induction of differentiation in 3T3-L1 cells (Fig. 2A,B). The FGFRs are encoded by four closely related genes with each isoform possessing distinct affinities for different ligands (Powers et al. 2000). A C-terminally truncated mutant of FGFR-1 (FGFR-1TR) has been shown to inhibit signal transduction by virtually all FGFR isoforms by dimerizing with them and blocking trans-phosphorylation (Ueno et al. 1992). Adenovirus-mediated expression of FGFR-1TR in 3T3-L1 preadipocytes prevented activity of MAP kinase or p70S6 kinase induced by FGF10 (data not shown). Expression of FGFR1TR by an adenovirus vector in 3T3-L1 preadipocytes also prevented lipid accumulation (Fig. 2C) as well as the expression of C/EBP $\alpha$ and PPAR $\gamma$ (data not shown). Infection of the cells with an adenovirus vector encoding $\beta$-galactosidase affected neither lipid accumulation (Fig. 2C) nor expression of adipocyte-marker proteins (data tiation (Cao et al. 1991; Yeh et al.

not shown). These results indicated that FGF10 participates in differentiation of preadipocytes through an autocrine/paracrine mechanism.

During preadipocyte differentiation, the expression of $\mathrm{C} / \mathrm{EBP} \beta$ and $\mathrm{C} / \mathrm{EBP} \delta$ isoforms is induced early and transiently; the subsequent increase in the expression of $\mathrm{C} / \mathrm{EBP} \alpha$ and $\operatorname{PPAR} \gamma$, in turn, results in the activation of a variety of adipocyte-specific genes (Hwang et al. 1997; Rosen and Spiegelman 2000). Among these transcription factors, $C / E B P \beta$ is thought to play a major role at an early stage of differen1995; Wu et al. 1996). Addition of FGF10Ab to the induction medium (Fig. 3A) or expression of FGFR-1TR (data not shown) inhibited the expression of $\mathrm{C} / \mathrm{EBP} \beta$ mRNA and protein, which normally become maximal at $2 \mathrm{~d}$ after differentiation of 3T3-L1 cells, indicating that FGF10 contributes to the expression of C/EBP $\beta$ at this stage of differentiation. However, the onset of expression of the $C / E B P \beta$ gene precedes that of the FGF10 gene; whereas $C / E B P \beta$ mRNA was detected at $6 \mathrm{~h}, F G F 10$ mRNA was not apparent until $12 \mathrm{~h}$ after the induction of differentiation (Fig. 3B), suggesting that FGF10 is not required for the induction of C/EBP $\beta$, but, rather, contributes to maintain the expression of C/EBP $\beta$ at a relatively late phase of differentiation. Indeed, addition of FGF10Ab to the induction medium did not affect the abundance of $\mathrm{C} / \mathrm{EBP} \beta$ protein at $6 \mathrm{~h}$ postinduction, at which stage FGF10 was not induced; however, the abundance of C/EBP $\beta$ protein at 24 and $48 \mathrm{~h}$ postinduction was markedly reduced (Fig. 3C). Moreover, when FGF10Ab was added to the medium at $6 \mathrm{~h}$ postinduction, a similar decrease in the abundance of $\mathrm{C} / \mathrm{EBP} \beta$ protein at 24 and $48 \mathrm{~h}$ was observed (Fig. 3C). Ectopic expression of an active form of C/EBP $\beta$ (LAP, $\mathrm{p} 34$ ) induced the expression of PPAR $\gamma$ and C/EBP $\alpha$ proteins as well as lipid accumulation in cells in which FGF10 signaling was blocked either by FGF10Ab (Fig. 4) or FGFR-1TR (data not shown), indicating that expression of $\mathrm{C} / \mathrm{EBP} \beta$ rescued differentiation of the cells. Together, these data suggest that, although $\mathrm{C} / \mathrm{EBP} \beta$ is induced via an FGF10independent mechanism, FGF10 is necessary for maintaining the abun-

A

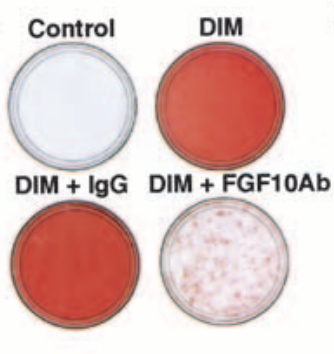

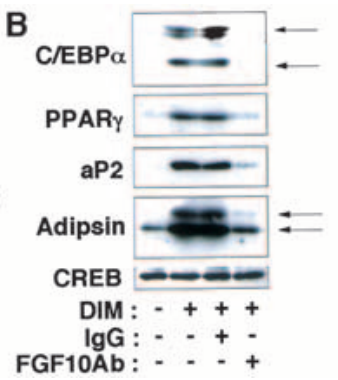

C

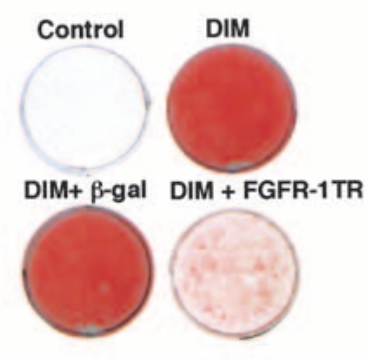

Figure 2. Effects of FGF10Ab or FGFR-1TR on adipocyte differentiation. 3T3-L1 cells were incubated in the absence (Control) or presence of inducers of differentiation (DIM), FGF10Ab, or control $\operatorname{IgG}(20 \mu \mathrm{g} / \mathrm{mL})$, as indicated, and were harvested after $8 \mathrm{~d}$. (A) The cells were stained with oil red $\mathrm{O}$ or $(B)$ subjected to immunoblot analysis with antibodies to C/EBP $\alpha$, to PPAR $\gamma$, to aP2, to adipsin, or to CREB. (C) 3T3-L1 cells infected or not with adenovirus vectors encoding FGFR-1TR or $\beta$-galactosidase ( $\beta$-gal) were incubated in the absence (Control) or presence of inducers of differentiation (DIM) and were stained (after $8 \mathrm{~d}$ ) with oil red O. Data are representative of three experiments dance of C/EBP $\beta$ and consequently contributes to the progress of the adipocyte differentiation program in 3T3-L1 cells.

To elucidate the physiological impact of FGF10 action in adipogenesis in vivo, we investigated the development of adipose tissue in mice lacking the FGF10 gene (Sekine et al. 1999). We first examined the temporal expression profile of the FGF10 gene in wild-type mouse embryos. In contrast to the expression profile during the differentiation of 3T3-L1 cells, the onset of expression of the FGF10 gene precedes that of the $C / E B P \beta$ gene during mouse embryogenesis. Whereas FGF10 mRNA was detected in subcutaneous WAT 


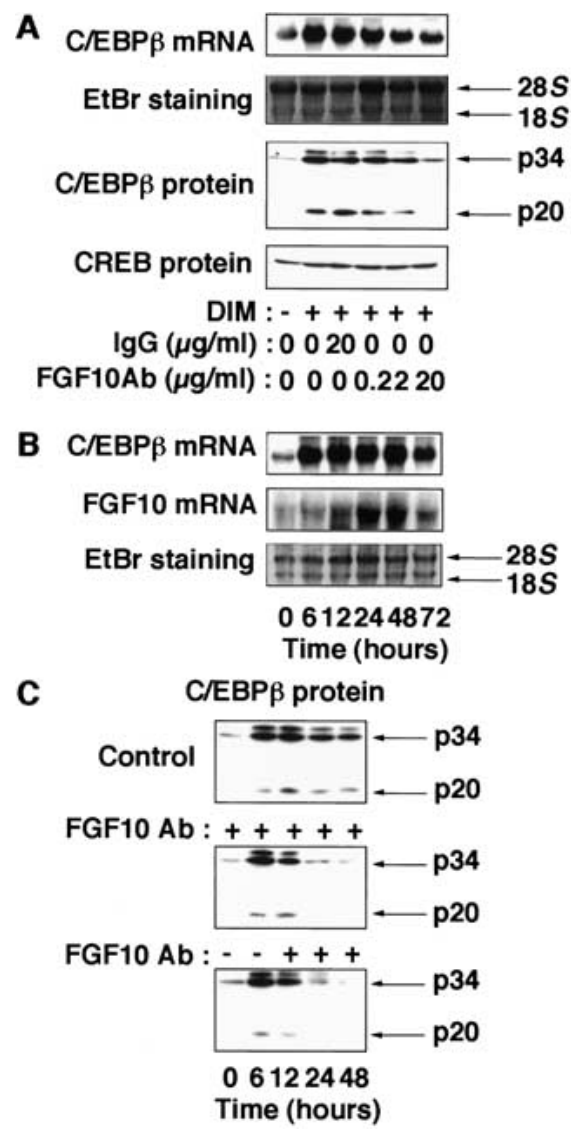

Figure 3. Effects of FGF10Ab on the expression of C/EBP $\beta$. (A) 3T3-L1 cells were incubated in the absence or presence of inducers of differentiation (DIM), and the indicated concentration of FGF10Ab or control IgG. The abundance of C/EBP 3 mRNA and protein, and CREB protein at $2 \mathrm{~d}$ postinduction is shown. $(B)$ Time course of the expression of FGF10 and C/EBP $\beta$ during differentiation. 3T3-L1 cells incubated for the indicated times after the onset of exposure to inducers of differentiation were subjected to Northern blot analysis for FGF10 or C/EBPß. (C) 3T3-L1 cells incubated for the indicated times after the onset of exposure to inducers of differentiation in the presence (middle and lower panels) or absence (upper panel) of FGF10Ab $(20 \mu \mathrm{g} / \mathrm{mL})$. (C, middle panel) FGF10Ab was present through the whole time course of differentiation; (lower panel) FGF10Ab was added to the media at $6 \mathrm{~h}$ postinduction. Data are representative of three experiments.

on embryonic day 16.5 (E16.5) and increased thereafter, $C / E B P \beta$ mRNA was not detected until E17.5 (Fig. 5A). FGF10 knockout mice are slightly $(\sim 15 \%)$ shorter in length than their wild-type littermates, and they die immediately after birth as a result of impaired lung development (Min et al. 1998; Sekine et al. 1999). We therefore examined the histology of abdominal subcutaneous WAT of neonatal mice. Development of subcutaneous WAT in FGF10 knockout neonates was markedly impaired, and the expression of the C/EBP $\beta$ gene in this tissue was greatly decreased (Fig. 5B). We also examined the histology of FGF10 knockout embryos at E18.5, and a similar reduction of WAT was observed (data not shown), suggesting that the reduction of WAT in FGF10 knockout neonates is caused not by their perinatal lethality, but, rather, by defects in developmental processes. In contrast to the sharp reduction of WAT, interscapular BAT of FGF10 knockout neonates was well developed, and distinct expression of C/EBP $\beta$ was apparent in this tissue. Although the amount of BAT in FGF10 knockout neonates was slightly smaller than that in wild-type littermates, this difference may reflect the difference in body size between the two genotypes. These observations suggested that FGF10 plays an essential role in the development of WAT, but not in that of BAT, consistent with the fact that the expression of FGF10 is restricted to WAT (Yamasaki et al. 1999). Furthermore, the ability of embryonic fibroblasts (EFs) derived from FGF10 knockout mice to differentiate into adipocytes, as assessed by lipid accumulation and the abundance of $C / E B P \alpha$ and PPAR $\gamma$ mRNA, was significantly reduced (Fig. 5C,D), also indicating that FGF10 is important in differentiation of adipocytes.

We have shown that FGF10 is secreted from cultured preadipocytes during differentiation, and that the prevention of FGF10 signaling inhibited differentiation of preadipocytes. Moreover, disruption of the FGF10 gene resulted in a marked reduction in the amount of subcutaneous WAT, but not of BAT, in mice, and the ability of EFs derived from FGF10 knockout mice to differentiate into adipocytes was impaired. Together, these observations indicate that FGF10 plays an important role in the development of WAT by regulating the differentiation of preadipocytes. The ability of EFs to differentiate into adipocytes was not completely prevented by disruption of the FGF10 gene. Because EFs are heterogeneous, it is possible that they secrete an unidentified factor that can partially rescue the lack of FGF10, or they may contain progenitor cells that differentiate into brown adipocytes, which appear to differentiate via an FGF10-independent mechanism.

The prevention of FGF10 signaling inhibited the expression of C/EBP $\beta$ during differentiation of 3T3-L1 cells, and an active form of C/EBP $\beta$ rescued differentiation of the cells in which FGF10 signaling was blocked. Moreover, the expression of C/EBP $\beta$ in WAT of FGF10 knockout mice was markedly reduced. These data collectively suggest that FGF10 plays an important role in adipogenesis, at least partly by contributing to the expression of C/EBP $\beta$. In 3T3-L1 preadipocytes, the inhibition of FGF10 signaling did not affect the abundance of $\mathrm{C} / \mathrm{EBP} \beta$ at $6 \mathrm{~h}$ postinduction, whereas that at $48 \mathrm{~h}$

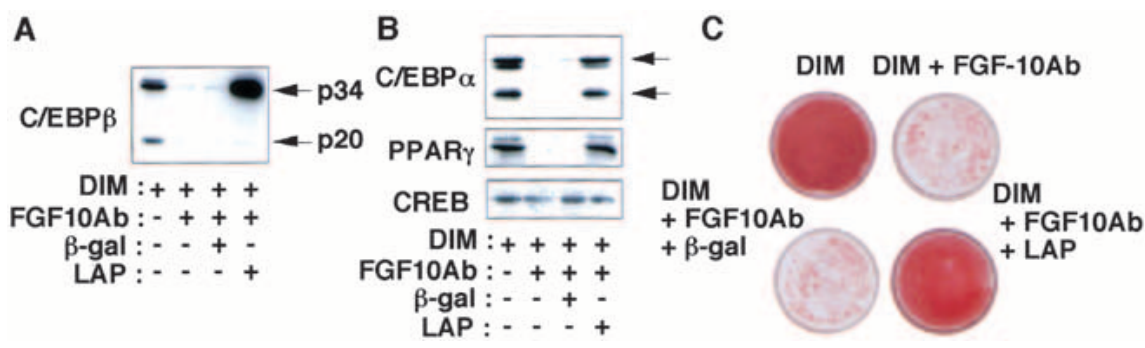

Figure 4. Effects of FGF10Ab and an active form of $C / E B P \beta$ on adipocyte differentiation. 3T3-L1 cells were infected or not with adenovirus vectors encoding an active form of C/EBP (LAP) or $\beta$-galactosidase ( $\beta$-gal) at an m.o.i. of 10 PFU per cell. The cells were then incubated in the presence of inducers of differentiation (DIM) and with or without FGF10Ab $(20 \mu \mathrm{g} / \mathrm{mL})$ and were harvested after $2 \mathrm{~d}(A)$ or $8 \mathrm{~d}(B, C)$. Cells were subjected to immunoblot analysis with antibodies to $\mathrm{C} / \operatorname{EBP} \beta(A)$; to $\mathrm{C} / \operatorname{EBP} \alpha, \operatorname{PPAR} \gamma$, or to $\operatorname{CREB}(B)$; or were stained with oil red $\mathrm{O}(C)$. Data are representative of three experiments. 


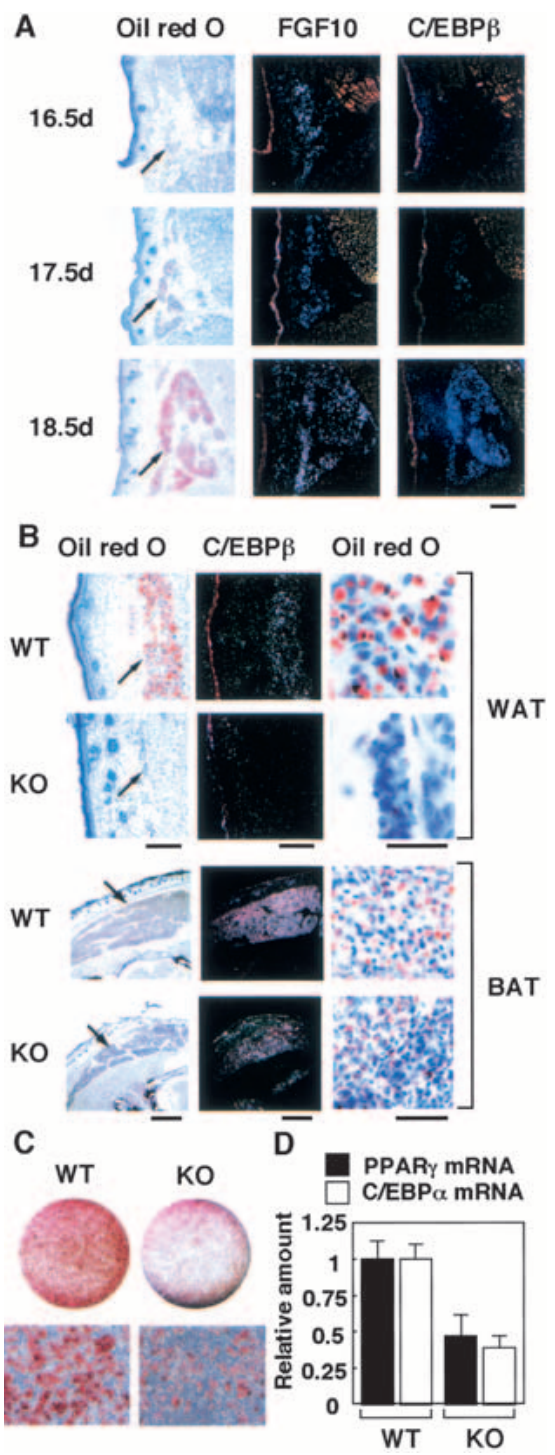

Figure 5. Expression of FGF10 genes in WAT during mouse embryogenesis, histological analysis of WAT and BAT of FGF10 knockout neonates, and the ability of $\mathrm{EF}$ to differentiate into adipocytes. (A) Expression of FGF10 and C/EBP $\beta$ genes in subcutaneous WAT of wild-type mouse embryos at E16.5, E17.5, and E18.5. Sections were stained with oil red $\mathrm{O}$ or subjected to in situ hybridization with ${ }^{35}$ S-labeled FGF10 or C/EBP $\beta$ antisense RNA probes. Scale bar, 100 $\mu \mathrm{m}$. Arrows indicate subcutaneous WAT. (B) Subcutaneous WAT and interscapular BAT of FGF10 knockout $(\mathrm{KO})$ mice and wild-type (WT) littermates (within 10 min after birth) were stained with oil red O or subjected to in situ hybridization with a ${ }^{35}$ S-labeled C/EBP $\beta$ antisense RNA probe. Scale bars, $100 \mu \mathrm{m}$. Macroscopic (left panels) and microscopic (right panels) views of oil red $\mathrm{O}$ staining are shown. Arrows indicate WAT and BAT. At least three neonates of each genotype were examined, and representative data are shown. $(C, D)$ EF obtained form FGF10 knockout mice or wild-type littermates were incubated in the inducers of differentiation for $8 \mathrm{~d}$, then the cells were stained with oil red $\mathrm{O}(C)$, or the abundance of $C / E B P \alpha$ or PPAR $y$ mRNA was determined by real-time PCR $(D)$. $(C$, upper panels) Macroscopic and (C, lower panels) microscopic views of oil red $\mathrm{O}$ staining. Data in $C$ are representative of three experiments and in $D$ are means \pm SEM of values from six experiments.

postinduction was markedly reduced, suggesting that expression of C/EBP $\beta$ during differentiation of these cells occurs in two discrete steps: early induction in an
FGF10-independent manner and maintenance by an FGF10-dependent mechanism. Incubation of 3T3-L1 preadipocytes with FGF10 alone induced neither induction of C/EBP $\beta$ nor differentiation of preadipocytes (data not shown), also suggesting that FGF10 alone is not sufficient for the initiation of differentiation of preadipocytes, but, rather, that it coordinately regulates adipogenesis with other factors.

Although various secreted factors that affect adipocyte differentiation have been described (Hwang et al. 1997; Rosen and Spiegelman 2000; MacDougald and Mandrup 2002), it has remained unclear which of these factors is responsible for induction of the complex program of gene expression that underlies this process in vivo. FGFs, expressed in specific spatial and temporal patterns, function as key intercellular signaling molecules in development of various tissues (Goldfarb 1996; Ornitz and Itoh 2001). Our data suggest that FGF10 is an endogenous regulator that is required for the development of WAT. The mechanism by which the FGF10 gene is activated and the downstream effectors of FGF10 signaling during adipogenesis remain to be characterized; however, our data may provide a new aspect for the understanding of adipogenesis as well as of the pathogenesis of obesity.

\section{Materials and methods}

Antibodies

The antibodies to $\mathrm{C} / \mathrm{EBP} \alpha$, to $\mathrm{C} / \mathrm{EBP} \beta$, and to FGF10 (C-17) used for neutralizing experiments were obtained from Santa Cruz Biotechnology. The antibodies to FGF10 used for immunoblot analysis were produced by immunization of hens with recombinant human FGF10 (Emoto et al. 1997). The antibodies to PPAR $\gamma$ (Hu et al. 1996) and adipsin (Cook et al. 1987) were kindly provided by B.M. Spiegelman; those to aP2 (Bernlohr et al. 1985) were kindly provided by D. Bernlohr.

Cell culture and adenovirus vectors

Vascular-stromal cells prepared from mouse epididymal adipose tissue as described (Mitchell et al. 1997) or 3T3-L1 preadipocytes were induced to differentiate by treating for $2 \mathrm{~d}$ with insulin $(5 \mu \mathrm{g} / \mathrm{mL}), 25 \mu \mathrm{M}$ DEX, and $0.5 \mathrm{mM}$ IBMX in the presence of $10 \%$ fetal bovine serum, and then for 2 $\mathrm{d}$ with insulin $(5 \mathrm{\mu g} / \mathrm{mL})$. After incubation with these reagents, the basal medium was replenished every other day. EFs obtained from E14.5 embryos as described (Miki et al. 2001) were induced to differentiate by treating with insulin $(10 \mu \mathrm{g} / \mathrm{mL}), 250 \mu \mathrm{M} \mathrm{DEX}$, and $0.5 \mathrm{mM} \mathrm{IBMX}$ in the presence of $10 \%$ fetal bovine serum for $8 \mathrm{~d}$. The adenovirus vector encoding FGFR-1TR was as described (Ueno et al. 1997); that encoding $\beta$-galactosidase was kindly provided by I. Saito (Tokyo University, Japan). Complementary DNA encoding a constitutively active form of C/EBP $\beta$ (LAP, containing amino acids 21-296) was constructed from the mouse wild-type $C / E B P \beta$ cDNA (kindly provided by $\mathrm{S}$. Akira, Osaka University, Japan); an adenovirus vector containing this cDNA was generated with an adenovirus expression kit (Takara) as described (Sakaue et al. 1998). For adenovirus-mediated gene transfer, cells cultured to subconfluency were infected with viruses at the indicated multiplicity of infection (m.o.i.). Two days after infection, differentiation was induced as described above.

Real-time quantitative PCR, Northern blot, and immunoblot analyses For real-time quantitative PCR analysis, cDNAs synthesized from total RNA extracted from cells were analyzed in a model 7700 Sequence Detector (PE Applied Biosystem) with primers as follows: FGF10-specific primers, sense: 5' -CCAAGAATGAAGACTGTCCGTACA-3', antisense: 5'-TGGCTTTGACGGCAACAAC-3', and probe: 5'-TGTCCTGGAGAT AACATCAGTGGAAATCGG-3'; PPAR $\gamma$-specific primers, sense: $5^{\prime}$-CC CAGAGCATGGTGCCTT-3', antisense: 5'-GGCATCTCTGTGTCAAC CATGGT-3', and probe: 5'-CTGATGCACTGCCTATGAGCACTTCA CA-3'; C/EBP $\alpha$-specific primers, sense: 5'-CGCCTTCAACGACGAG TTC-3', antisense: 5' ${ }^{\prime}$ TTGGCCTTCTCCTGCTGTC-3', and probe: $5^{\prime}-$ TGGCCGACCTCTTCCAGCACAG-3' 
The total RNA extracted from cells was subjected to Northern blot analysis with full-length mouse FGF10 cDNA (Tagashira et al. 1997) or a fragment of mouse PPAR $\gamma$ cDNA (Sakaue et al. 1998) as probes. Cell lysates $(\sim 100 \mu \mathrm{g}$ of protein) were subjected to immunoblot analysis as described (Sakaue et al. 1998). For detection of FGF10 in culture medium $20 \mu \mathrm{L}$ of immobilized heparin beads was incubated with $20 \mathrm{~mL}$ of medium; the beads were washed, and the bound proteins were eluted by boiling in SDS sample buffer and then subjected to immunoblot analysis.

Histological analysis and in situ hybridization

FGF10 knockout mice and wild-type littermates were generated by intercrossing of mice heterozygous for disruption of the FGF10 gene (Sekine et al. 1999). Neonatal FGF10 knockout and wild-type littermates (within $10 \mathrm{~min}$ after birth), or wild-type embryos at the indicated stages of development, were frozen in powdered dry ice. Transverse sections of the animals were fixed with formaldehyde and stained with oil red $\mathrm{O}$ or subjected to hybridization with ${ }^{35}$ S-labeled mouse FGF10 or C/EBP $\beta$ antisense RNA probes. The histology of abdominal subcutaneous WAT and interscapular BAT was analyzed.

\section{Acknowledgments}

We thank I. Saito, S. Akira, D. Bernlohr, and B.M. Spiegelman for an adenovirus vector encoding $\beta$-galactosidase, $C / E B P \beta$ cDNA, antibodies to aP2, and antibodies to PPAR $\gamma$ and to adipsin, respectively. This work was supported by grants from the Ministry of Education, Culture, Science, Sports, and Technology of Japan (to W.O. and N.I.), a grant-in-aid for the Research for the Future Program from the Japan Society for the Promotion of Science (to M.K.), and a grant from the Human Frontier Science Program (to N.I.)

The publication costs of this article were defrayed in part by payment of page charges. This article must therefore be hereby marked "advertisement" in accordance with 18 USC section 1734 solely to indicate this fact.

\section{References}

Bernlohr, D.A., Doering, T.L., Kelly, T.J., Jr., and Lane, M.D. 1985. Tissue specific expression of $\mathrm{p} 422$ protein, a putative lipid carrier, in mouse adipocytes. Biochem. Biophys. Res. Commun. 132: 850-855.

Cao, Z., Umek, R.M., and McNight, S.L. 1991. Regulated expression of three C/EBP isoforms during adipose conversion of 3T3-L1 cells. Genes \& Dev. 5: 1538-1552.

Cook, K.S., Min, H.Y., Johnson, D., Chaplinsky, R.J., Flier, J.S., Hunt, C.R., and Spiegelman, B.M. 1987. Adipsin: A circulating serine protease homolog secreted by adipose tissue and sciatic nerve. Science 237: 402-405.

Emoto, H., Tagashira, S., Mattei, M.G., Yamasaki, M., Hashimoto, G., Katsumata, T., Negoro, T., Nakatsuka, M., Birnbaum, D., Coulier, F., et al. 1997. Structure and expression of human fibroblast growth factor-10. J. Biol. Chem. 272: 23191-23194.

Fruebis, J., Tsao, T.S., Javorschi, S., Ebbets-Reed, D., Erickson, M.R., Yen, F.T., Bihain, B.E., and Lodish, H.F. 2001. Proteolytic cleavage product of $30-\mathrm{kDa}$ adipocyte complement-related protein increases fatty acid oxidation in muscle and causes weight loss in mice. Proc. Natl. Acad. Sci. 98: 2005-2010.

Goldfarb, M. 1996. Functions of fibroblast growth factors in vertebrate development. Cytokine Growth Factor Rev. 7: 311-325.

Hu, E., Kim, J.B., Sarraf, P., and Spiegelman, B.M. 1996. Inhibition of adipogenesis through MAP kinase-mediated phosphorylation of PPAR $\gamma$. Science 274: 2100-2103.

Hwang, C.-S., Loftus, T.M., Mandrup, S., and Lane, M.D. 1997. Adipocyte differentiation and leptin expression. Annu. Rev. Cell. Dev. Biol. 13: 231-259.

Lau, D.C.W., Roncari, D.A.K., and Hollenberg, C.H. 1987. Release of mitogenic factors by cultured preadipocytes from obese human subjects. J. Clin. Invest. 79: 632-636.

MacDougald, O.A. and Mandrup, S. 2002. Adipogenesis: Forces that tip the scales. Trends Endocrinol. Metab. 13: 5-11.

Miki, H., Yamauchi, T., Suzuki, R., Komeda, K., Tsuchida, A., Kubota, N., Terauchi, Y., Kamon, J., Kaburagi, Y., Matsui, J., et al. 2001. Essential role of insulin receptor substrate 1 (IRS-1) and IRS-2 in adipocyte differentiation. Mol. Cell. Biol. 21: 2521-2532.
Min, H., Danilenko, D.M., Scully, S.A., Bolon, B., Ring, B.D., Tarpley, J.E., DeRose, M., and Simonet, W.S. 1998. Fgf-10 is required for both limb and lung development and exhibits striking functional similarity to Drosophila branchless. Genes \& Dev. 12: 3156-3161.

Mitchell, S.E., Rees, W.D., Hardie, L.J., Hoggard, N., Tadayyon, M., Arch, J.R., and Trayhurn, P. 1997. ob gene expression and secretion of leptin following differentiation of rat preadipocytes to adipocytes in primary culture. Biochem. Biophys. Res. Commun. 230: 360-364.

Ornitz, D.M. and Itoh, N. 2001. Fibroblast growth factors. Genome Biol. 2: 3005.1-3005.12.

Petrunschke, T. and Hauner, H. 1994. Tumor necrosis factor- $\alpha$ prevents the differentiation of human adipocyte precursor cells and causes delipidation of newly developed fat cells. J. Clin. Endocrinol. Metab. 76: 742-747.

Powers, C.J., McLeskey, S.W., and Wellstein, A. 2000. Fibroblast growth factors, their receptors and signaling. Endocr. Relat. Cancer 7: 165197.

Rosen, E.D. and Spiegelman, B.M. 2000. Molecular mechanism of adipogenesis. Annu. Rev. Cell. Dev. Biol. 16: 145-171.

Ross, S.E., Hemati, N., Longo, K.A., Bennett, C.N., Lucas, P.C., Erickson, R.L., and MacDougald, O.A. 2000. Inhibition of adipogenesis by Wnt signaling. Science 289: 950-953.

Sakaue, H., Ogawa, W., Matsumoto, M., Kuroda, S., Takata, M., Sugimoto, T., Spiegelman, B.M., and Kasuga, M. 1998. Posttranscriptional control of adipocyte differentiation through activation of phosphoi nositide (PI) 3-kinase. J. Biol. Chem. 273: 28945-28952.

Schillabeer, G., Forden, J.M., and Lau, D.C.W. 1989. Induction of preadipocyte differentiation by mature fat cells in the rat. I. Clin. Invest. 84: $381-387$.

Sekine, K., Ohuchi, H., Fujiwara, M., Yamasaki, M., Yoshizawa, T., Sato, T., Yagishita, N., Matsui, D., Koga, Y., Itoh, N., et al. 1999. Fgf10 is essential for limb and lung formation. Nat. Genet. 21: 138-141.

Smas, C.M., Chen, L., and Sul, H.S. 1997. Cleavage of membrane-associated pref-1 generates a soluble inhibitor of adipocyte differentiation. Mol. Cell. Biol. 17: 977-987.

Steppan, C.M., Bailey, S.T., Bhat, S., Brown, E.J., Banerjee, R.R., Wright, C.M., Patel, H.R., Ahima, R.S., and Lazar, M.A. 2001. The hormone resistin links obesity to diabetes. Nature 409: 307-312.

Tagashira, S., Harada, H., Katsumata, T., Itoh, N., and Nakatsuka, M. 1997. Cloning of mouse FGF10 and up-regulation of its gene expression during wound healing. Gene 197: 399-404.

Ueno, H., Gunn, M., Dell, K., Tseng, A., Jr., and Williams, L. 1992. A truncated form of fibroblast growth factor receptor 1 inhibits signal transduction by multiple types of fibroblast growth factor receptor. J. Biol. Chem. 267: 1470-1476.

Ueno, H., Li, J.J., Masuda, S., Qi, Z., Yamamoto, H., and Takeshita, A 1997. Adenovirus-mediated expression of the secreted form of basic fibroblast growth factor (FGF-2) induces cellular proliferation and angiogenesis in vivo. Arterioscler. Thromb. Vasc. Biol. 17: 2453-2460.

Wu, Z., Bucher, N.L.R., and Farmer, S.R. 1996. Induction of peroxisome proliferative activated protein $\gamma$ during the conversion of $3 \mathrm{~T} 3$ fibroblasts into adipocytes is mediated by $\mathrm{C} / \mathrm{EBP} \beta, \mathrm{C} / \mathrm{EBP} \delta$, and glucocorticoids. Mol. Cell. Biol. 16: 4128-4136.

Yamasaki, M., Miyake, A., Tagashira, S., and Itoh, N. 1996. Structure and expression of the rat mRNA encoding a novel member of the fibroblast growth factor family. I. Biol. Chem. 271: 15918-15921.

Yamasaki, M., Emoto, H., Konishi, M., Mikami, T., Ohuchi, H., Nakao, K., and Itoh, N. 1999. FGF-10 is a growth factor for preadipocytes in white adipose tissue. Biochem. Biophys. Res. Commun. 258: 109112.

Yamashita, T., Yoshioka, M., and Itoh, N. 2000. Identification of a novel fibroblast growth factor, FGF-23, preferentially expressed in the ventrolateral thalamic nucleus of the brain. Biochem. Biophys. Res. Commun. 277: 494-498.

Yeh, W.C., Cao, Z., Classon, M., and McKnight, S.L. 1995. Cascade regulation of terminal adipocyte differentiation by three members of the C/EBP family of leucine zipper proteins. Genes \& Dev. 15: 168-181. 


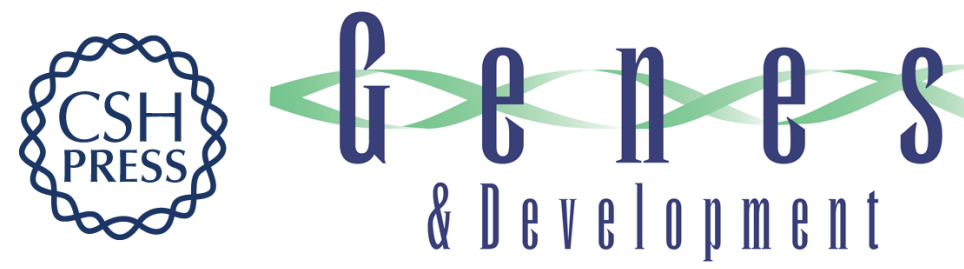

\section{Requirement of fibroblast growth factor 10 in development of white adipose tissue}

Hiroshi Sakaue, Morichika Konishi, Wataru Ogawa, et al.

Genes Dev. 2002, 16:

Access the most recent version at doi:10.1101/gad.983202

References This article cites 29 articles, 15 of which can be accessed free at:

http://genesdev.cshlp.org/content/16/8/908.full.html\#ref-list-1

License

Email Alerting Receive free email alerts when new articles cite this article - sign up in the box at the top right corner

Service of the article or click here.

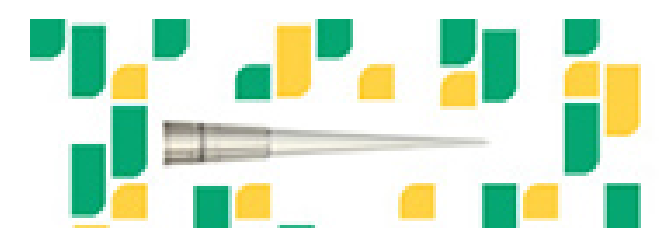

Focused on your science. 